\title{
Influence of the Planting Distance and the Crown Shape on the Fruit Harvest and the Productive Potential of Cherry Trees in a High-Density System
}

\author{
Igor IVANOV, Valerian BALAN*, Ananie PEŞTEANU, Sergiu VAMASESCU, Petru BALAN and Vasile \\ SARBAN
}

Faculty of Horticulture, The State Agrarian Universtity of Moldova, Chisinau

*Corresponding author: v.balan@uasm.md

Bulletin UASVM Horticulture 75(2) / 2018

Print ISSN 1843-5262, Electronic ISSN 1843-536X

DOI:10.15835/buasvmcn-hort: 2018.0014

\begin{abstract}
Cherry technology is permanently modernized due to new varieties, vegetal rootstocks and new tree management systems. The cherry varieties "Bigarreau Burlat", "Ferrovia" and "Lapins", grafted on Gisela 6 (Prunus cerasus $\times$ Prunus canescens) rootstock at distances of $5 \times 1.5 \mathrm{~m} ; 5 \times 2.0 \mathrm{~m} ; 5 \times 2.5 \mathrm{~m}$, were studied in the southern area of the Republic of Moldova. The trees were shaped by the Ameliorated natural reduced-volume crown and Slender Spindle Ameliorated form. Cherry trees start to yield in the fourth year after planting; the largest total fruit production from the tree was obtained in the variant with trees planted at a distance of $5 \times 2.5 \mathrm{~m}$ and per hectare, when the trees were planted at a distance of $5 \times 1.5 \mathrm{~m}$. In the fourth year of yielding, the production of "Ferrovia" cherry variety, where the trees were shaped by the Ameliorated natural crown with low volume constituted 15368-18155 kg/ha, and at the time the "Slender Spindle Ameliorated" form, constituted 16904 $-20074 \mathrm{~kg} / \mathrm{ha}$. Although the results are preliminary, it seems that high-density planting systems combined with low-power vegetal rootstocks and improved crowns can give higher yields of cherries in the first 4 years than the traditional improved crown system with low volume.
\end{abstract}

Keywords: cherry, crown shape, harvest, planting distance, variety

\section{Introduction}

The capacity to produce quality cherries is determined by the variety, rootstock, plant density, tree management and vigor, age and position of the fruit branches, fruit tree load, pesticide usage and growth regulators, environmental factors and agrotechnical management (Ampatzidis and Whiting 2013; Long et al., 2014).

The correct management of fruit crops largely depends on the correct selection of pollinating varieties, combined with the appropriate rootstock, the crown shape and the planting distance corresponding to the culture system (Calabro et al., 2009; Long et al., 2014; Musacchi et al., 2015).
Irrespectively of the crown management system, the forming cuttings and maintenance cuttings must ensure the formation of a ventilated and balanced crown, must lead to early high harvesting, to the formation of predominantly vertical half-skeleton, which provides high quality fruits, the harvesting of the fruits from the ground with high efficiency to obtain high quality fruits, reduction of the final height of trees, cyclic renewal of semi skeleton branches. (Whiting et al., 2005; Long et al., 2014; Balan, 2015).

The Republic of Moldova has a satisfactory climate for cherry orchards farming with high density system. Many of the current orchards are still of traditional type. The Government of the Republic of Moldova offers attractive subsidies for 
those who invest in the establishment of modern cherry orchards.

Cherry growing technology is permanently modernized due to new varieties, new vegetal rootstocks and new tree management systems. Usage of low force rootstocks, in full compliance with the modern forms of tree management, allowed to establish cherry orchards with high density.

Considering the economic advantages of the new tree culture system, we need to establish the planting distance of the trees, acording to the crown shape, the vigor of the varieties and the rootstocks used (Balan, 2015).

\section{Materials and methods}

Investigations regarding the establishment of highly productive cherry plantations have been carried out in the southern area of the Republic of Moldova. The orchard was established in the spring of 2009-th in the company SRL „Terra Vitis” in the village of Burlacu, Cahul district using cherry rootstock Gisela 6, grafted with cherry varieties "Bigarreau Burlat", " Ferrovia", "Lapins", at a distance of $5 \times 1.5 \mathrm{~m}, 5 \times 2 \mathrm{~m}, 5 \times 2.5 \mathrm{~m}$. The trees were shaped by ameliorated natural crown with low-volume (control) and "Ameliorated Slender Spindle".

The experimental design was based on the rotation plan in accordance with the methodology of organizing the factorial experiments of the Мойсейченко et al. (1994). The interaction between planting distance and crown shape was studied as basic factors which determine the trees yielding, harvest and fruit quality.

The studies and observations were made in order to develop rational methods for the planting scheme of the tree, forming and pruning crown, adjustment of growth and yielding processes. The experiment was organized in four repetitions with eight representative trees in each repetition. The scheme was based on the polyfactorial principle with the planting scheme of the variants through the randomized block system on two rows in the middle of the band for each variety.

Crown forming and tree vigor were controlled by the sectoral double pruning method (Balan 1997). The pruning of branches exceeded half of the branch growth vigor and was aimed at optimizing the ratio between the growth of vegetative and reproductive organs in order to accelerate the entry of trees on fruit. The semi-skeleton branches were periodically renewed by rotation every 3-4 years.

Fruit harvesting was performed at the maturation stage, considering the skin color, according to the CTIFL color sheet and the soluble dry matter content. The harvest establishment for each variety was carried out individually by weighing the fruits from 32 trees in the variant.

The statistically significant differences of the research results were verified, using the dispersion analysis method described by Docnexov (1985), in Microsoft Office Excel 2003. In order to determine the statistically significant differences the method of differences limit (LSD) for 5\% probabilities was used.

\section{Results and discussion}

Pruning and crown formation was subordinated to variety's biology and shape of crowns planned to obtain early crops, constant quality, highlighting the effectiveness of culture at different densities and simplify the technology management and trees maintenance (Milatović et al., 2013, 2015).

Data in Tables 1, 2 and 3 show that "Bigarreau Burlat", "Ferrovia" and "Lapins" varieties grafted on rootstock Gisela 6, started to yield in 4-th year of vegetation. The first fruit harvest constituted 0.4-0.6 kg/tree in "Bigarreau Burlat" variety, 0.7$0.8 \mathrm{~kg} /$ tree in "Ferrovia" variety and $0.5 \mathrm{~kg} /$ tree in "Lapins" variety.

Economically efficient crops have been obtained from 5-th year after planting. In the third year of yielding, cherry varieties have doubled fruit harvest. In "Bigarreau Burlat" varieties, the trees were shaped by the ameliorated natural crown with low volume, and the cherry fruit harvest was $8.56-10 \mathrm{~kg} /$ tree, and for he trees which were shaped by the Slender spindle ameliorated the harvest constituted $8.93-12.75 \mathrm{~kg} /$ tree. The planting distance of $5 \times 1.5 \mathrm{~m}$ was recorded that significantly differed from the planting distances of $5 \times 2 \mathrm{~m}$ and $5 \times 2.5 \mathrm{~m}$.

In the „Ferrovia” and "Lapins" varieties the cherry harvest also decreased during the growing and yeilding season, that was direct proportional to the increase of trees density. Thus, if the "Ferrovia" trees were shaped by the ameliorated natural crown with low volume at the planting distance of $5 \times 1.5 \mathrm{~m}$, the cherry yield was 9.54 $\mathrm{kg} /$ tree. At the planting distance of $5 \times 2.5 \mathrm{~m}$ the 
Table 1. Fruit harvest of the "Bigarreau Burlat" cherry tree determined by the crown shape and planting distance. (Rootstock Gisela 6, tree age 4-7 years, S.R.L. Terra Vitis)

\begin{tabular}{|c|c|c|c|c|c|c|}
\hline \multirow{2}{*}{ Crown shape } & \multirow{2}{*}{$\begin{array}{c}\text { Planting } \\
\text { distance, } m\end{array}$} & \multicolumn{4}{|c|}{ Years, kg/tree } & \multirow{2}{*}{$\begin{array}{c}\text { Amount, } \mathrm{kg} / \\
\text { tree } \\
(2013-2016)\end{array}$} \\
\hline & & 2013 & 2014 & 2015 & 2016 & \\
\hline \multirow{3}{*}{$\begin{array}{l}\text { Ameliorated natural crown with low } \\
\text { volume (control) }\end{array}$} & $5 \times 1.5$ & 0.6 & 4.47 & 8.56 & 13.49 & 27.12 \\
\hline & $5 \times 2$ & 0.4 & 4.89 & 9.15 & 14.82 & 29.26 \\
\hline & $5 \times 2.5$ & 0.4 & 4.65 & 10.00 & 18.27 & 33.32 \\
\hline \multirow{3}{*}{ Slender spindle ameliorated } & $5 \times 1.5$ & 0.4 & 4.75 & 8.93 & 14.21 & 28.29 \\
\hline & $5 \times 2$ & 0.5 & 5.12 & 11.82 & 15.16 & 32.6 \\
\hline & $5 \times 2.5$ & 0.5 & 5.21 & 12.75 & 19.54 & 38.0 \\
\hline LSD 5\% & & - & - & 1.94 & 2.72 & \\
\hline
\end{tabular}

Table 2. Yielding of "Ferrovia" cherry determined by the crown shape and planting distance. (Rootstock Gisela 6, tree age 4-7 years, S.R.L. Terra Vitis)

\begin{tabular}{|c|c|c|c|c|c|c|}
\hline \multirow{2}{*}{ Crown Shape } & \multirow{2}{*}{$\begin{array}{l}\text { Planting } \\
\text { distance, } \mathrm{m}\end{array}$} & \multicolumn{4}{|c|}{ Years, kg/tree } & \multirow{2}{*}{$\begin{array}{c}\text { Amount, } \mathrm{kg} / \\
\text { tree } \\
(2013-2016)\end{array}$} \\
\hline & & 2013 & 2014 & 2015 & 2016 & \\
\hline \multirow{3}{*}{$\begin{array}{l}\text { Ameliorated natural crown with low } \\
\text { volume (control) }\end{array}$} & $5 \times 1.5$ & 0.7 & 4.81 & 9.54 & 13.62 & 28.67 \\
\hline & $5 \times 2$ & 0.7 & 5.26 & 12.35 & 15.92 & 34.23 \\
\hline & $5 \times 2.5$ & 0.7 & 5.56 & 14.12 & 19.21 & 39.59 \\
\hline \multirow{3}{*}{ Slender spindle ameliorated } & $5 \times 1.5$ & 0.8 & 5.13 & 10.37 & 15.06 & 31.36 \\
\hline & $5 \times 2$ & 0.8 & 5.58 & 13.13 & 17.81 & 37.32 \\
\hline & $5 \times 2.5$ & 0.8 & 6.27 & 16.08 & 21.13 & 44.28 \\
\hline LSD 5\% & & - & - & 3.34 & 2.65 & \\
\hline
\end{tabular}

Table 3. Yielding of "Lapins" cherry variety determined by the crown shape and planting distance (Rootstock Gisela 6, tree age 4-7 years, S.R.L. Terra Vitis)

\begin{tabular}{|c|c|c|c|c|c|c|}
\hline \multirow{2}{*}{ Crown shape } & \multirow{2}{*}{$\begin{array}{c}\text { Planting } \\
\text { distance, m }\end{array}$} & \multicolumn{4}{|c|}{ Years, kg/tree } & \multirow{2}{*}{$\begin{array}{c}\text { Amount, } \mathrm{kg} / \\
\text { tree } \\
(2013-2016)\end{array}$} \\
\hline & & 2013 & 2014 & 2015 & 2016 & \\
\hline \multirow{3}{*}{$\begin{array}{l}\text { Ameliorated natural crown with low } \\
\text { volume (control) }\end{array}$} & $5 \times 1.5$ & 0.5 & 4.11 & 9.21 & 13.92 & 27.74 \\
\hline & $5 \times 2$ & 0.5 & 4.58 & 9.40 & 17.24 & 31.72 \\
\hline & $5 \times 2.5$ & 0.5 & 4.65 & 12.36 & 20.19 & 37.7 \\
\hline \multirow{3}{*}{ Slender spindle ameliorated } & $5 \times 1.5$ & 0.5 & 4.35 & 8.90 & 14.54 & 28.29 \\
\hline & $5 \times 2$ & 0.5 & 5.01 & 9.90 & 18.21 & 33.62 \\
\hline & $5 \times 2.5$ & 0.5 & 5.25 & 11.90 & 21.92 & 39.57 \\
\hline LSD 5\% & & & & 1.98 & 4.12 & \\
\hline
\end{tabular}


harvest constituted $14.12 \mathrm{~kg} /$ tree. When the trees were shaped by the improved thinning form, the fruit harvest was also higher at the planting distance of $5 \times 2.5 \mathrm{~m}$ compared to the trees planted at a distance of $5 \times 1.5 \mathrm{~m}$ and $5 \times 2 \mathrm{~m}$. In the "Lapins" variety, the size of the fruit harvest, depending on the shape and planting distance of the crown, have registered the same regularity as in the varieties "Bigarreau Burlat" and "Ferrovia".

In the fourth year of yielding, the amount of harvested fruits increased in comparison with the last year, when the fruit production was 13.49 to $19.54 \mathrm{~kg} /$ tree in "Bigarreau Burlat", 13.62$21.13 \mathrm{~kg} /$ tree in "Ferrovia" and 13.92-21.92 kg/ tree in "Lapins". The cherry trees, shaped by the natural reduced-volume crown, provided an insignificantly smaller fruit quantity as compared to those with improved thinning form.

The quantity of the fruit harvest was significantly differentiated, depending on the planting distance between the trees in a row. Thus, in "Bigarreau Burlat" variety, the trees shaped by the ameliorated natural crown with low volume, the fruit harvest, at the planting distance of $5 \times 2.5 \mathrm{~m}$ was $18.27 \mathrm{~kg} /$ tree, while at distance of $5 \times 1.5 \mathrm{~m}$ the harvest was only $13.49 \mathrm{~kg} /$ tree.

The trees planted at the distance of $5 \times 2.5 \mathrm{~m}$ and shaped by the thinned improved form, showed the highest harvest values, distinctly significant by 22.4-27.3\%.

In "Ferrovia" and "Lapins" varieties, the harvest also increased once with the increase of the distance between trees in a row, and reached the maximum value at the planting distance of $5 \times 2.5$ m. Thus, for the "Ferrovia" and "Lapins" varieties, the trees shaped by the improved natural crown reduced the volume of the harvested fruits at the planting distance of $5 \times 2.5 \mathrm{~m}$; the harvest was respectively 19.21 and $20.19 \mathrm{~kg} /$ tree, while at the planting distance of $5 \times 1.5 \mathrm{~m}$, the harvest was only 13.62 and $13.92 \mathrm{~kg} /$ tree.

Irrespectively of the variety and crown shape, the trees of the "Bigerreau Burlat", "Ferrovia" and "Lapins" varieties, grafted on Gisela 6, started to yeild in the fourth year after planting. The fruit harvest decreased as the tree density increased. For example, in the "Bigarreau Burlat" variety, in the trees, shaped by the natural reduced-volume crown, the harvested quantity was ranging from $27.12 \mathrm{~kg} /$ tree $(5 \times 1.5 \mathrm{~m})$ to $33.32 \mathrm{~kg} /$ tree $(5 \times 2.5$ $\mathrm{m})$. In the trees shaped by the improved thinning form the harvested quantity was ranging from $28.29 \mathrm{~kg} /$ tree $(5 \times 1.5 \mathrm{~m})$ up to $38 \mathrm{~kg} /$ tree $(5 \times 2.5 \mathrm{~m})$. The same results were recorded in the "Ferrovia" and "Lapins" varieites in the sense that in the first four years of yielding, the amount of the harvest per tree is higher when the planting distances are bigger.

Taking in consideration the density of trees in a row, it is important to appreciate the influence of the studied factors on fruit harvest that depends on the surface of nourishment (Tab. 4, 5, 6).

In the first year of yielding, the fruit harvest inrrespectively of the variety and shape of the crown, was directly proportional with the number of trees per hectare. Thus, in "Bigarreau Burlat" varieties, the fruit harvest was ranging from $320 \mathrm{~kg} / \mathrm{ha}(5 \times 2.5 \mathrm{~m})$ to $799 \mathrm{~kg} / \mathrm{ha}(5 \times 1.5 \mathrm{~m})$. In the next 3 years of yielding, the fruit harvest also increased as the tree density increased. For example, in the "Ferrovia" variety, shaped by the improved thinning form, at the planting distance of $5 \times 1.5 \mathrm{~m}$, the fruit harvest in 2016 was 18942 $\mathrm{kg} / \mathrm{ha}$, and at a distance of $5 \times 2.5 \mathrm{~m}$ was only $15632 \mathrm{~kg} / \mathrm{ha}$. Harvest increases are significantly different for the trees located at a planting distance of $5 \times 1.5 \mathrm{~m}$ in comparaison with the trees planted at a distance of $5 \times 2.5 \mathrm{~m}$ in all studied varieties and crown shapes.

Studying different planting distances in cherry trees allowed us to conclude that, in the first years of yeilding, the yielding capacity was very similar among all the varieties. In the following years it was observed that in high density plantations the trees had lower yield. Calculated at the surface unit in the variants with the dense placement of the trees, the harvest is higher compared with those which was rarefied.

In the following years of yielding, the harvest obtained from the trees, shaped by the improved thinning form, irrespectively of the variety and planting distance, was higher compared to the plantations, where the trees were shaped by the natural reduced-volume crown. For example, in the fourth year of yielding (2016), the production of cherries in the "Ferrovia" variety, where the trees were shaped by the natural reduced-volume crown, was $15368-18155 \mathrm{~kg} / \mathrm{ha}$, and the cherry production in those, which were shaped by Slender spindle ameliorated, was in quantity of $16904-20074 \mathrm{~kg} / \mathrm{ha}$. In the "Lapins" variety, the highest yields significantly differed,-and they also 
Table 4. Yeilding of "Bigarreau Burlat" cherry variety determined by the crown shape and planting distance (Rootstock Gisela 6, tree age 4-7 years, S.R.L. Terra Vitis)

\begin{tabular}{ccccccc}
\hline \multirow{2}{*}{ Crown shape } & $\begin{array}{c}\text { Planting } \\
\text { distance, } \mathbf{m}\end{array}$ & $\mathbf{2 0 1 3}$ & $\mathbf{2 0 1 4}$ & $\mathbf{2 0 1 5}$ & $\mathbf{2 0 1 6}$ & $\begin{array}{c}\text { Amount, kg/ } \\
\text { tree } \\
\mathbf{2 0 1 3 - 2 0 1 6 )}\end{array}$ \\
\cline { 3 - 7 } & $5 \times 1.5$ & 799 & 5962 & 11410 & 17982 & 36153 \\
\hline \multirow{2}{*}{$\begin{array}{c}\text { Ameliorated natural crown with low } \\
\text { volume (control) }\end{array}$} & $5 \times 2$ & 400 & 4893 & 9150 & 15160 & 29603 \\
\cline { 2 - 7 } & $5 \times 2.5$ & 320 & 3722 & 8000 & 14616 & 26658 \\
\hline \multirow{2}{*}{\begin{tabular}{c} 
Slender spindle ameliorated \\
\cline { 2 - 7 }
\end{tabular}} & $5 \times 1.5$ & 711 & 6339 & 12209 & 18942 & 38201 \\
\hline & $5 \times 2$ & 500 & 5120 & 11820 & 16160 & 33600 \\
\hline LSD 5\% & & - & - & 851 & 1237 & - \\
\hline
\end{tabular}

Table 5. Yielding of the "Ferrovia" cherry variety determined by the crown shape and planting distance (Rootstock Gisela 6, tree age 4-7 years, S.R.L. Terra Vitis)

\begin{tabular}{|c|c|c|c|c|c|c|}
\hline \multirow{2}{*}{ Crown shape } & \multirow{2}{*}{$\begin{array}{l}\text { Planting } \\
\text { distance, } \mathrm{m}\end{array}$} & \multicolumn{4}{|c|}{ Years, kg/tree } & \multirow{2}{*}{$\begin{array}{c}\text { Amount, kg/ } \\
\text { tree } \\
(2013-2016)\end{array}$} \\
\hline & & 2013 & 2014 & 2015 & 2016 & \\
\hline \multirow{3}{*}{$\begin{array}{c}\text { Ameliorated natural crown with low } \\
\text { volume (control) }\end{array}$} & $5 \times 1.5$ & 931 & 6397 & 12716 & 18155 & 38199 \\
\hline & $5 \times 2$ & 700 & 5260 & 12350 & 15920 & 34230 \\
\hline & $5 \times 2.5$ & 560 & 4448 & 9881 & 15368 & 30257 \\
\hline \multirow{3}{*}{ Slender spindle ameliorated } & $5 \times 1.5$ & 1066 & 6822 & 13823 & 20074 & 41785 \\
\hline & $5 \times 2$ & 800 & 5580 & 13130 & 17810 & 37320 \\
\hline & $5 \times 2.5$ & 640 & 5016 & 12864 & 16904 & 35424 \\
\hline LSD 5\% & & - & - & 576 & 1342 & \\
\hline
\end{tabular}

Table 6. Yielding in "Lapins" cherry variety determined by the crown shape and planting (Rootstock Gisela 6, tree age 4-7 years, S.R.L. Terra Vitis)

\begin{tabular}{|c|c|c|c|c|c|c|}
\hline \multirow[b]{2}{*}{ Crown shape } & \multirow{2}{*}{$\begin{array}{c}\text { Planting } \\
\text { distance, } \mathrm{m}\end{array}$} & \multicolumn{4}{|c|}{ Years, kg/tree } & \multirow{2}{*}{$\begin{array}{c}\text { Amount, kg } \\
\text { tree } \\
(2013-2016\end{array}$} \\
\hline & & 2013 & 2014 & 2015 & 2016 & \\
\hline \multirow{3}{*}{$\begin{array}{l}\text { Ameliorated natural crown with low } \\
\text { volume (control) }\end{array}$} & $5 \times 1.5$ & 666 & 5478 & 12277 & 18555 & 3697 \\
\hline & $5 \times 2$ & 500 & 4580 & 9400 & 17240 & 31720 \\
\hline & $5 \times 2.5$ & 400 & 3720 & 9888 & 16152 & 30160 \\
\hline \multirow{3}{*}{ Slender spindle ameliorated } & $5 \times 1.5$ & 666 & 5799 & 11864 & 19382 & 37711 \\
\hline & $5 \times 2$ & 500 & 5010 & 9900 & 18210 & 33620 \\
\hline & $5 \times 2.5$ & 400 & 4200 & 9520 & 17536 & 31656 \\
\hline LSD 5\% & & - & - & 475 & 879 & \\
\hline
\end{tabular}


were obtained in the trees shaped by the slender spindle ameliorated, in comparaison with the tree shaped by ameliorated natural crown with low volume.

If we summarize the fruit production on the tree and per hectare, during trees growing and yeilding, the differences of the harvest are very high. The highest production per tree (33.32$38.0 \mathrm{~kg}$ ) in the "Bigarreau Burlat" variety was obtained at a distance of $5 \times 2.5 \mathrm{~m}$ and the smallest production $(27.12-28.29 \mathrm{~kg})$ - at a distance of $5 \times 1.5 \mathrm{~m}$. However, calculated per ha, the highest productivity was recorded at the planting distance of $5 \times 1.5 \mathrm{~m}$, providing $36153-38201 \mathrm{~kg} / \mathrm{ha}$ and the lowest $26658-30403 \mathrm{~kg} / \mathrm{ha}$ at a distance of $5 \times 2.5$ $\mathrm{m}$. The same findings were also recorded in the "Ferrovia" and "Lapins" varieties which means that the largest production per tree was obtained in variants with bigger planting distances and calculated at ha - in high density plantations.

\section{Conclusion}

The "Bigarreau Burlat", "Ferrovia" and "Lapins" cherry varieties, grafted on Gisela 6, started to yeild in the fourth year after planting, providing the largest total fruit production on the tree in the first 4 years of harvesting with the $5 \times 2.5 \mathrm{~m}$ distance between the trees, and per ha - when the trees were planted at a distance of $5 \times 1.5 \mathrm{~m}$.

Shaping the trees after the sophisticated thin crown helped to increase the fruit production of the cherry plantations, compared to those where the trees were led after natural crown ameliorated with low volume.

\section{References}

1. Ampatzidis YG. and Whiting MD. (2013). Training System Affects Sweet Cherry Harvest Efficiency. HortScience, 48(5):547-555.

2. Balan V (1997). Metode de tăiere a ramurilor pomilor fructiferi: Brevet de invenţie RM, nr. 360. Publ.: BOPI nr. 1/96, 4 p.

3. Balan V (2015). Tehnologii în intensificarea culturii mărului şi cireşului. Academos, 2:74-79.

4. Calabro JM, Spotts RA, Grove GG (2009). Effect of Training System, Rootstock, and Cultivar on Sweet Cherry Powdery Mildew Foliar Infections. HortSciense, 44:481-482.

5. Long LE, Long M, Peșteanu A, Gudumac E (2014). Producerea Cireșelor. Manual tehnologic. Chișinău, 2014.

6. Milatović PD, Đurović BD, Đorđević SB, Vulić BT, Zec NZ (2013). Pomološke osobine novijih sorti trešnje na podlozi Colt. [Pomological properties of sweet cherry cultivars grafted on 'Colt' rootstock.] Journal of Agricultural Sciences, 58:61-72.

7. Milošević T, Milošević N, Glišić I, Nikolić R, Milivojević J (2015). Early tree growth, productivity, fruit quality and leaf nutrients content of sweet cherry grown in a high density planting system. Hort. Sci. Prague, 42(1):1-12.

8. Musacchi S, Gagliardi F, Serra S (2015). New Training Systems for High-density Planting of Sweet Cherry. HortScience, January, 50(1):59-67.

9. Whiting MD, Lang G, Ophardt D (2005). Rootstock and Training System Affect Sweet Cherry Growth, Yield, and Fruit Quality. HortScience, 40(3):582-586.

10. Доспехов Б. А. (1985). Методика полевого опыта. Москва: Агропромиздат, 351p.

11. Мойсейченко В. Ф., Заверюха, А. Х., Трифанова, М. Ф. (1994): Основы научных исследований в плодоводстве, овощеводстве и виноградарстве. Колос, Мосkва, 365p. 